\section{International Scientific Journal Theoretical \& Applied Science}

p-ISSN: 2308-4944 (print) $\quad$ e-ISSN: 2409-0085 (online)

Year: $2018 \quad$ Issue: $01 \quad$ Volume: 57

Published: $30.01 .2018 \quad$ http://T-Science.org
Saidamirxon A'loxon o'g'li Makhmudov Master of National University named after Mirzo Ulugbek Tashkent, Uzbekistan kamola_nuz@rambler.ru saidamirxon.mahmudov.1994@mail.ru

SECTION 13. Geography. History. Oceanology. Meteorology.

\title{
COMPOSITION AND STRUCTURE OF BOOKS REGISTRATION OF JUDICIAL INSTITUTIONS OF TASHKENT AND SIGNIFICANCE OF THESE SOURCES (1868-1924)
}

\begin{abstract}
The article is devoted to the study of the books of registration of cases considered in judicial institutions of the Turkestan Territory after $1867 \mathrm{y}$. The structure of the books on registration of judicial institutions, the language of texts, their importance as an important historical source, examples of books of the congresses of the congress, as well as books of four districts of the city of Tashkent have been studied relatively well. The article explores the problems and provisions related to the documentation in the judicial institutions.

Key words: Turkestan region, Tashkent, judicial institutions, congress of kazis, Kazas, historical documents, act, decision.

Language: English

Citation: Makhmudov SA (2018) COMPOSITION AND STRUCTURE OF BOOKS REGISTRATION OF JUDICIAL INSTITUTIONS OF TASHKENT AND SIGNIFICANCE OF THESE SOURCES 1868-1924. ISJ Theoretical \& Applied Science, 01 (57): 72-75.

Soi: http://s-o-i.org/1.1/TAS-01-57-14 Doi: crossef https://dx.doi.org/10.15863/TAS.2018.01.57.14
\end{abstract}

\section{Introduction}

As a result of the establishment of the Governor-General in Turkestan in 1867, large-scale reforms began in the judiciary in the province. One of these reforms is the establishment of a book of registration of court cases, examined by the Sharia court judges. Today in the Central State Archive of the Republic of Uzbekistan there are books on registration of manufactured vessels by the cities, counties and parishes of Samarkand, Syrdarya and Ferghana provinces of Turkestan general governorate [1: 90-99]. Among them, it is important to note a complete list of documents for the years 1868-1924 relating to congresses of courts and people's court(judges) of the four judicial bodies of the administrative districts of Tashkent. The importance of these documents lies in the fact that they cover a great historical period.

\section{Materials and Methods}

For this reason, in this article, we have tried, with the example of books on registering the affairs of Tashkent, to note their significance as an important historical source.

Judicial institutions of a new type in the city of Tashkent were first created on the basis of the "Provisional Regulations on the Management of the
Turkestan", adopted on August 6, 1865. Later, on July 11,1867 , this document was supplemented with the "Regulations on the Management of the Djetysu and Syrdarya Region". In accordance with the "Regulations", as in other regions of the Turkestan region, schools were established for courts, elected for three years and dealing with cases on a case-bycase basis, a congress of courts and three types of extraordinary people's judges were assembled on their basis.

At the congress of the court of the four regions of Tashkent, unresolved issues were considered. Each congress had one of four delegates, that is, a chairman, called sadrneshin (header of the congress) [2: 293].

Books of registrations of judicial institutions of the Courts of Tashkent region are located in the Central State Archive in the following order:

362-fund. Congress of courts of Tashkent city. 59 cases. $1869-1916$ years.

363-fund. Court of Beshayagach district. 97 cases. 1869-1916 years.

364-fund. Court of the Kukchi district. 91 thing. 1870-1924 years.

365-fund. Court of the Sebzar region. 94 cases. 1869-1924 years. 
366-fund. Court Shaykhontakhur district. 111 cases. 1868-1923 years.

In these funds there are only 510 cases, each of them consists of an average of 30-150 pages. Most of the documents are intertwined in the form of separate books in thick cardboard, and individual pieces are stitched in a thin blue cover. The ordinal number of these notebooks in the archive does not exactly match the chronological sequence of the cases examined. For example, the first case, considered in the Kukchi district, refers to 1869 , the second - to 1877 , the third to 1872 , the fourth - by 1880 . Books of registration between the specified years can be lost. Individual books with defects, that is, they do not have either initial or final pages. In addition, in the 36-fund of the office of the head of Tashkent there are about twenty books of registrations concerning the years 1878-1880 [3]. One book of registration of the kazi of the Kukchi district is kept at the Center for Oriental Manuscripts at the Tashkent State Institute of Oriental Studies [4: 4145].

Previously, these books were the elders of four districts of the city. They recorded announcements, orders, various events (cases of theft, violence, violation of order) relating to residents of the Old City and approved by the seal of the headman [5]. Later, in connection with the changes that took place in the administrative management of the city, the conduct of such books by the village elder was terminated and it was imposed by the court of the district. But now they did not fix the ads of the city administration, as it was before, but the content of the cases examined in the judicial institutions [6].

According to the established procedure, the court bought notebooks for their money in the office of the head of the city of Tashkent on their own statement. They were sewn with a special thread in the form of books, and were stamped with the seal of the responsible person of the city administration (the head of the department, the manager of affairs or the secretary), and then they were handed to the court. The date indicated in the book corresponds to the date that indicates the time before the institution of this book, this indicates that this or that case was carried out before the book was received by the courts. Books were received by the courts at the beginning of the year, even before the end of the current year. For example, the 11th case concerning Court of Kukchi was started in October 1887, and it is the continuation of the 10th case, which was filled just this month [7]. The completed books of registrations were again handed over to the office of the head of the city of Tashkent. Over time, the city administration sought to improve the maintenance of books of registration of court cases. In particular, the city administration introduced an innovation in the internal structure of books and the procedure for registering cases. Thus, she sought to create conveniences for verifying the judicial transactions carried out. For this reason, the registers of the 60-70 $y$. of the XIX century differ significantly from the internal structure of the books of subsequent times.

The handwriting in the book of registration of judicial institutions after 1865 looks much worse than the handwriting of traditional documents, there are many possible mistakes in them. It was from 1865 that the "revolution" began in the language of office work. The Uzbek language (Chigatay Turkish language) was chosen as the mediator of the local population with state institutions. The written appeal of the local population to state institutions and the authorities of the province was carried out in that language. But within the judicial institutions it was not easy to switch to the Turkic language. In the conduct of registration books in the judicial institutions, Persian-Turkish bilingualism arose. This was even seen within the same text. For example, there are cases of presentation of land and property issues in traditional Persian, and the presentation of the final part of the definition of the court in the Turkic language [8: 2, 83, 86, 102]. However, in a number of cases, when drawing up a vakf letter (a document on the transfer of any property to a Muslim religious institution), documents on buying and selling, renting or hiring, the conclusions given by the mufti on some legal or legal matter on the basis of Sharia law, as before, the Persian language took the leading place, because when composing such documents it is difficult to quickly introduce the exact Turkic synonyms of the Persian expressions in the forms that existed for many centuries. Perhaps, therefore, concerning the documents of administrative records management, there is a strong influence of Arabic and Persian languages in the documents of judicial institutions.

All types of judicial and legal documentation experienced a long historical process, changes in structure and content occurred in the deep and superficial structures of the text, a specific, peculiar language-a document form-was formed. In connection with the transition to the Turkic language in judicial proceedings, there was an ambiguous change in the texts of documents of traditional judicial institutions. First, in the structure and components of documents, adaptation to the system of Russian records management (transition to Christian chronology, ordinal numbers, parallel placement of the original and translation texts, etc.) is observed. Secondly, do not pay attention to the letters expressing sounds in the Arabs in the texts and content of documents, the syllable system in words, the local forms of pronunciation of the words of Russian-European words ("roburte" - report, "chilon" - member, "isfrafka" - certificate, "kiftance" - receipt and etc.).

The books of the courts are divided into such types as the book of acts, which reflect the purchase 
and sale of real estate, hiring or renting issues, confession in wine, heritage distribution, representation, custody and a book of decisions that reflect the details of events, a summary of their results. A special instruction on record keeping and proper management of books of registers of the court has been developed. There are special tables on their pages, there is a procedure for filling them in Russian and Uzbek (in the Arabic alphabet) languages. In the columns of the table it was necessary to write down the contents of the rammed case, the decision of the court, the consent of the person applying to the court with the decision of court and information on obtaining extracts from the court decision. As for the content of the books of court, they are bought and sold (bayi bot), pledge (bayi joiiz), consent (hatti iqror), waiving the claim (hatti ibro), court decision, registration of citizens' documents, credentials, documents guardianship certificates, divorce certificates, various applications, gifts, distribution of inheritance, orders and announcements and documents approved by the seal of the court for local government affairs.

The forms of books of decisions and acts of judicial institutions established for the oblasts of Turkestan do not differ from each other. Previously, the notebooks consisted of simple blank sheets, only then they took the form of a book with special tables.

In the section on the management of the Turkestan on the activities of the courts, it is noted that citizens can copy (cut out) from the notebook information about the decision of the court and in another part of the notebook should subscribe from this [10: 30]. But in fact this position has not always been fulfilled. The maintenance of exercise books on the acts of the court of Sebzar in 1888 and the court of Kukchi in 1887 are completely different from each other. In the notebook of the court of Kukchi, the events are set out very briefly, and in the notebook of the court of Sebzar - on the contrary [11].

Notebooks of the court are mainly attested by a little, a simple seal of the court district. They had an oval, round and octagonal form and differed from the main, large round seal of the courts. They have very brief information about court, its name, position and date. Sometimes, along with a small seal, a document was approved, and the main one, with a large seal.

The calendars of the court Congress's were confirmed by the seals of the courts, who were present at the work of the congress, basically three or four seals were put up.

The originality of notebooks or books of registration can be related to the level of activity of the court who worked before the Russian reform and the representatives of the "intelligentsia" and their secretaries who occupied these posts by elections after 1867. It should be noted that the notebooks, staged by the main court of Tashkent by the son of Khakimhodzhi, court of Sebzar Muhitdinhodzhi, are characterized by a detailed description of the events, beautiful handwriting and a well-written account of the facts. Books of registrations of the 70-ies by the court of Shaykhontokhur were made out ugly and randomly. In general, mistakes and confusion were allowed in the conduct and filling of books of decisions of judges and notebooks of acts. Judging by the critical views of officials who checked these books, they made certain errors in the management of notebooks or books of registration [12].

\section{Conclusion}

Proceeding from all this, one can come to the conclusion that the books of judicial institutions established in the Turkestan region have emerged as a result of reforms of the judicial and legal system of colonial administration. Despite this, the books of judicial institutions, on the one hand, reflected the social life of that time and historical topography; on the other hand, they are an important written source of research on the activities of judicial institutions. The study of these sources will make it possible to explore the history of towns and villages in the future not only in the Tashkent region, but also in the Fergana and Samarkand regions.

\section{References:}

1. (1948) Guide. Central State Historical Archive of the UzSSR (Central State Archive of the Republic of Uzbekistan). Compilers: Agafonova ZI, Khalfin NA - T., 1948. - p.9099.

2. Sartori P. (2011) The Birth of a Custom: Nomads, Sharia Courts and Established Practices in the Tashkent Province, ca. 1868-
1919 // Islamic Law and Society. 2011. № 18. p.293-326.

3. (1877) Central State Archive of the Republic of Uzbekistan. Fund I-36, 1-list, 1657-1660, 18701877, 2168-2871-volume.

4. (2014) For details on this book, see Sultonov, About the court book which keeps under number 6361, stored in the Institute of Oriental 


\begin{tabular}{l|lrl|l|ll} 
& ISRA (India) & $=\mathbf{1 . 3 4 4}$ & SIS (USA) & $=\mathbf{0 . 9 1 2}$ & ICV (Poland) & $=\mathbf{6 . 6 3 0}$ \\
Impact Factor: & ISI (Dubai, UAE) $=\mathbf{0 . 8 2 9}$ & PUHL (Russia) $=\mathbf{0 . 2 0 7}$ & PIF (India) & $=\mathbf{1 . 9 4 0}$ \\
& GIF (Australia) & $\mathbf{0 . 5 6 4}$ & ESJI (KZ) & $=\mathbf{4 . 1 0 2}$ & IBI (India) & $=\mathbf{4 . 2 6 0}$ \\
& JIF & $\mathbf{1 . 5 0 0}$ & SJIF (Morocco) & $=\mathbf{2 . 0 3 1}$ & & \\
\hline
\end{tabular}

Studies // Theses of the XI scientific-practical conference named after U. Karimov) - T., 2014. - p.41-45

5. (2017) Central State Archive of the Republic of Uzbekistan. Fund I-363, 1-list, 2-work; Central State Archive of the Republic of Uzbekistan. I364 Fund, 1-list, 1-work; Central State Archive of the Republic of Uzbekistan. Fund I-366, 1list, 1-work. These sources on the Sebzar region are not found in the archive, they may have been lost.

6. Grodekov N.I. (1889) Kirghiz and Karakirgiz of the Syrdarya region. T.1. Legal life. - T., 1889. Annexes 2.

7. (2017) Central State Archive of the Republic of Uzbekistan. I-364 Fund, 1-list, 11-volume
8. TSGA of RUz. Fund I-365, 1-list, 46-work. 2, 83, 86, 102 and other pages.

9. (2017) Central State Archive of the Republic of Uzbekistan. I-365 Fund, 1-list, 2-work. 95-vol. sheet.

10. (1886) Regulations on the administration of the Turkestan Territory. Volume 2, part 2. - St. Petersburg, 1886. - p.30, - p.236.

11. (2017) Central State Archive of the Republic of Uzbekistan. Fund I-365, 1-list, 2-work; Central Administration of Civil Aviation of Uzbekistan. Foundation I-364, 1-list, 13-case.

12. (2017) Central State Archive of the Republic of Uzbekistan. I-36 Fund, 1-list, 3006-file. 